\title{
UPAYA PENANGKAPAN UNTUK MENGURANGI POPULASI IKAN ZEBRA (BRACHYDANIO RERIO) DI DANAU BERATAN KABUPATEN TABANAN PROVINSI BALI
}

\author{
I.W. Restu, I.W. Arthana, N.M. Ernawati, N.P.P. Wijayanti, M.A. Pratiwi, \\ dan E.W. Suryaningtyas ${ }^{1}$
}

\begin{abstract}
ABSTRAK
Provinsi Bali memiliki empat buah danau alam yang terletak di tiga kabupaten yaitu, Danau Beratan, di Kabupaten Tabanan, Danau Buyan dan Tamblingan di Kabupaten Buleleng dan Danau Batur di Kabupaten Bangli. Danau Beratan memiliki potensi sumberdaya perikanan dengan kekayaan jenis seperti : Ikan Mujair, Nila , Nilem, Karper, Nyalian, Lele, Gabus, Betok, Sepat, dan Ikan Zebra. Budidaya perikanan di sisi utara danau sudah dikembangkan dengan sistem keramba jaring apung (KJA). keberadaan ikan zebra yang dominan di suatu perairan menyebabkan pertumbuhannya menjadi lebih cepat daripada jenis ikan lainnya dan cenderung menjadi spesies pengganggu. Kondisi ini menyebabkan ketidakseimbangan sistem perikanan di Danau Beratan bahkan menimbulkan keresahan masyarakat nelayan yang menggantungkan hidupnya di perairan tersebut. Metode yang digunakan dalam melaksanakan kegiatan ini adalah metode penangkapan langsung (direct capture) bersama masyarakat nelayan dan pelaku lainnnya dengan mengunakan alat jaring kitcrik /pencar (hand net), alat jebak/bubu (trapper), serok atau ancho dan alat tangkap listrik (electrofishing). Metode yang lainnya adalah Focus Group Discussion (FGD) untuk memberikan pengetahuan dan pemahaman kepada Kelompok Nelayan Mina Puspa Merta, serta melakukan diskusi dan urun pendapat (umpan balik) tentang penanggulangan dan penangkapan ikan zebra yang merupakan masalah pokok di ekosistem perairan Danau Beratan. Populasi ikan zebra yang terus meningkat harus segera ditindaklanjuti dengan cara menangkapnya secara berkala, agar ikan-ikan asli atau ikan lokal yang bernilai ekonomis tinggi tidak hilang dari ekosistemnya.
\end{abstract}

Kata kunci : Ikan Zebra, Alat Tangkap, Danau Beratan, Populasi Ikan, Nelayan

\begin{abstract}
Bali Province has four natural lakes located in three regency namely, Beratan Lake, in Tabanan, Buyan and Tamblingan Lake in Buleleng and Batur Lake in Bangli Regency. Beratan Lake has the potential of fishery resources with a wealth of species such as Oreochromis mossambicus (Mozambique tilapia/Mujair), Oreochromis niloticus (Nile tilapia/Nila), Osteochilus vittatus (Nilem), Cyprinus carpio (Karper), Puntius binotatus (Nyalian), Clarias batrachus (Lele), Ophiocephalus striatus (Gabus), and Anabas testudineus (Betok), Trichogaster pectoralis (Sepat), and Brachydanio rerio (Zebra). Aquaculture on the north side of the lake has been developed with a floating net cage system (KJA). The presence of the dominant zebra fish in a
\end{abstract}

\footnotetext{
1 Staf Pengajar Program Studi Manajemen Sumberdaya Perairan, Fakultas Kelautan dan Perikanan, Universitas Udayana, e-mail: wayan.restu@ymail.com/_HP: 081339305923
} 
waters causes its growth to become faster than other fish species and tends to be a species of bullies. This condition causes the imbalance of fishery system in Beratan Lake even cause anxiety fisherman society which depend its life in those waters. The method used in carrying out this activity is direct capture method with fisherman community and other perpetrators by using tool nets/pencar (hand net), tool trap (trapper), serok or ancho and electric fishing equipment (electrofishing). The other method is the Focus Group Discussion (FGD) to provide knowledge and understanding to the Mina Puspa Merta Fishermen Group, as well as to conduct discussions and feedback on zebra prevention and fishing which is a fundamental problem in the waters ecosystem of Beratan Lake. The increasing population of zebra fish should be immediately followed up by catching it periodically, so that native fish or local fish with high economic value is not lost from the ecosystem.

Keywords: Zebra Fish, Fishing Gear, Beratan Lake, Fish Population, Fisherman

\section{PENDAHULUAN}

Provinsi Bali memiliki empat buah danau alam yang terletak di tiga kabupaten yaitu, Danau Beratan, di Kabupaten Tabanan, Danau Buyan dan Tamblingan di Kabupaten Buleleng dan Danau Batur di Kabupaten Bangli. Keempat danau tersebut memiliki fungsi yang sangat vital sebagai sumber daya alam khususnya bagi masyarakat Bali dan memiliki fungsi yang strategis untuk menunjang pembangunan perikanan di Provinsi Bali. Danau Beratan tepatnya terletak di Desa Candikuning, Kecamatan Baturiti, Kabupaten Tabanan. Danau Beratan dengan luas genangan 3,85 $\mathrm{km}^{2}$, panjang danau sekitar 7,5 km, lebar 2,0 km, kedalaman maksimum sekitar $20 \mathrm{~m}$, serta berada diketinggian $1.231 \mathrm{~m}$ di atas permukaan laut memiliki karakteristik berupa danau kaldera dengan sistem perairan yang tertutup (Hehanussa dan Haryani, 2009; BPS Provinsi Bali, 2010).

Lingkungan sekitar Danau Beratan lebih didominasi oleh keberadaa kawasan wisata, terutama kawasan Bedugul dan Pura Ulun Danu Beratan, serta beberapa tempat penginapan, lokasi pertanian, dan permukiman penduduk. Arthana et al. (2009) menyebutkan bahwa perubahan alih fungsi lahan dan perlakuan yang kurang bijaksana dalam eksploitasi sumber daya di Danau Beratan telah menyebabkan penurunan daya dukung danau tersebut. Pemanfaatan dan penguasaan lahan yang tidak terkendali pada sempadan sekitar Danau Beratan telah menyebabkan pendangkalan dan penurunan/penyusutan air danau yang cukup besar. Hal ini disebabkan karena tingkat kerusakan pada kawasan sekitar Danau Beratan telah mengalami kenaikan yang cukup signifikan akibat berkurangnya vegetasi pada kawasan tersebut.

Danau Beratan memiliki potensi sumberdaya perikanan dengan kekayaan jenis (species richness), seperti : ikan Mujair (Oreochromis mossambicus), Nila (Oreochromis niloticus), Nilem (Osteochilus hasselti), Karper (Cyprinus carpio), Nyalian (Rasbora sp.), Masan (Tor tambra), Lele (Clarias batrachus), Gabus (Ophiocephalus striatus), Betok (Anabas testudineus), Sepat (Trichogaster pectoralis) dan Ikan Zebra (Brachydanio rerio). Dan sudah dikembangkan budidaya perikanan di sisi utara danau dengan sistem keramba jaring apung (KJA).

Ikan zebra (Brachydanio rerio) adalah ikan asli dari Amerika Selatan (Scmitter-Soto, 2007). Menurut Froese dan Pauly (2011), ikan tersebut berukuran panjang baku kurang dari $10 \mathrm{~cm}$ dan memiliki ciri khas berupa garis vertikal hitam pada badannya sehingga ikan zebra juga biasa disebut convic cichlid. Ikan zebra mampu menghasilkan rata-rata 100-150 butir telur yang dijaga dengan ketat dan dirawat oleh ikan jantan dan betina (Yamamoto dan Tagawa, 2000). Ikan zebra menyenangi perairan berbatu dan sering ditemukan berlindung pada celah-celah retakan batuan atau pada akar tumbuhan dan ranting pohon yang jatuh (Conkel,1993). Ikan zebra merupakan ikan bentopelagis dan memiliki persebaran di perairan tawar daerah tropis dengan kisaran $\mathrm{pH}$ antara 7-8 
(Froese dan Pauly, 2011). Ikan tersebut mampu beradaptasi pada perairan yang dingin dan mampu hidup di danau vulkanis pada ketinggian $1.500 \mathrm{~m}$ di atas permukaan laut (Loiselle, 1995).

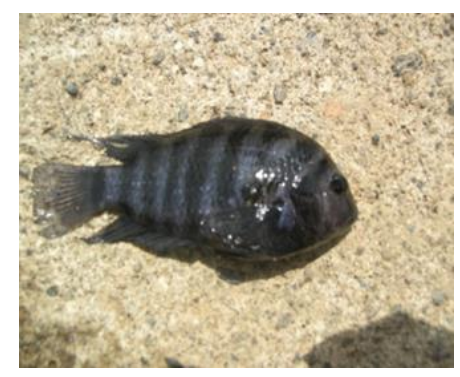

Gambar 1.1 Ikan Zebra (Brachydanio rerio)

Ikan zebra awalnya merupakan ikan hias yang terlepas secara tidak sengaja di Danau Beratan dan keberadaannya di danau tersebut dikhawatirkan berpotensi menjadi spesies asing invasif yang akan berdampak negatif terhadap komunitas ikan didalamnya. Dalam 10 tahun terakhir perkembangan ikan zebra (Brachydanio rerio) terjadi sangat pesat bahkan kelimpahan populasi jenis ini sangat dominan. Lee et al. (2011) menyatakan bahwa keberadaan ikan zebra yang dominan di suatu perairan menyebabkan pertumbuhannya menjadi lebih cepat daripada jenis ikan lainnya dan cenderung menjadi spesies pengganggu. Kondisi ini menyebabkan ketidakseimbangan sistem perikanan di Danau Beratan bahkan menimbulkan keresahan masyarakat nelayan yang menggantungkan hidupnya di perairan tersebut. Dengan terjadinya peledakan populasi ikan zebra yang tidak terkendali akan mengancam dan menyebabkan kelangkaan pada jenis-jenis ikan yang justru bernilai ekonomis dan merupakan sumber protein hewani dari perairan danau tersebut. Ikan zebra kurang disukai oleh masyarakat di sekitar Danau Beratan karena kurang bernilai ekonomis dari segi konsumsi.

Kondisi ini sangat merugikan dan meresahkan masyarakat nelayan di Danau Beratan dan sangat menggganggu keseimbangan sistem ekologi dan perikanan di Danau tersebut sehingga diperlukan langkah kongkrit untuk mengurangi kelimpahan populasi ikan zebra ini dari Danau Beratan. Kegiatan pengabdian kepada masyarakat berupa "Upaya Penangkapan Untuk Mengurangi Populasi Ikan Zebra (Brachydanio rerio) di Danau Beratan, Kabupaten Tabanan Provinsi Bali”, merupakan salah satu alternatif untuk menyelesaikan permasalahan masyarakat nelayan di Danau Beratan.

\section{METODE PELAKSANAAN}

\subsection{Tahap persiapan}

Melakukan survei lokasi pengabdian ke Danau Beratan, Kabupaten Tabanan, Provinsi Bali. Survei ini bertujuan untuk mengetahui kondisi wilayah di sekitar Danau Beratan dan melakukan koordinasi dengan Bendesa Adat Kembang Merta dan Kelompok Nelayan Mina Puspa Merta di Danau Beratan. Kemudian menyiapkan alat-alat yang akan digunakan pada saat pengabdian seperti alat jaring pencar dan juga menyiapkan umpan untuk menangkap ikan zebra.

\subsection{Tahap pelaksanaan}

Setelah tahap persiapan selesai maka kegiatan pertama yang dilakukan adalah melakukan diskusi dengan metode Focus Group Discussion (FGD) bersama Bendesa Adat Kembang Merta dan juga Kelompok Nelayan Mina Puspa Merta di Danau Beratan. Acara diskusi ini sangat penting karena Kelompok Nelayan akan mendapat banyak pengetahuan baru dan akan mendapat pemecahan 
masalah jika terdapat masalah di lapangan. Selanjutnya kegiatan penangkapan ikan zebra di Danau Beratan bisa dilaksanakan. Kegiatan ini bertujuan untuk mengurangi populasi ikan zebra karena jika populasinya terus bertambah akan merugikan nelayan. Pertumbuhan ikan zebra sangat cepat dibandingkan ikan lain yang ada di Danau Beratan. Jika hal ini terus terjadi maka ikan yang bernilai ekonomis bisa mengalami kelangkaan karena ledakan populasi ikan zebra sehingga penangkapan ikan zebra perlu dilakukan secara kontinyu.

\subsection{Tahap evaluasi}

Tahap evaluasi dilakukan untuk memonitoring hasil kegiatan pengabdian di Danau Beratan. Melalui kegiatan pengabdian ini nantinya diharapkan minat Kelompok Nelayan Mina Puspa Merta meningkat untuk menangkap ikan zebra karena populasi ikan zebra di Danau Beratan sangat tinggi.

\section{HASIL DAN PEMBAHASAN}

Sebelum pelaksanaan kegiatan, masyarakat nelayan yang tergabung dalam Kelompok Nelayan Mina Puspa Merta melakukan pemasangan bubu, jaring dan sorok/ancho yang sudah diberi umpan di beberapa titik lokasi penangkapan ikan zebra. Hal ini bertujuan agar ketika pelaksanaan kegiatan dijadwalkan, alat tangkap yang dipasang sudah sudah terisi ikan zebra yang tertangkap. Beberapa alat tangkap yang dipakai dalam kegiatan pengabdian seperti gambar dibawah ini:
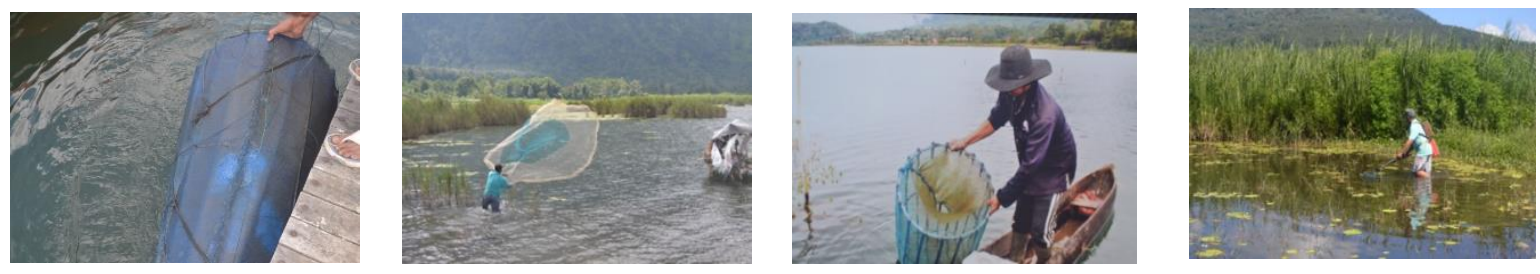

Gambar 3.1 Alat tangkap yang digunakan (kiri-kanan) yaitu alat tangkap bubu, pencar (jala lempar), ancho angkat, dan alat tangkap strum (electrofishing)

Kegiatan FGD ini difokuskan pada kelompok sasaran yaitu Kelompok Nelayan Puspa Mina Merta. Dalam diskusi dan pemaparan materi, tercatat ada 4 poin penting yang sangat strategis sebagai hasil FGD dan disarankan untuk ditindak lanjuti sampai pada instansi terkait, meliputi :

1. Keberadaan ikan zebra (Branchydanio rerio) di Danau Beratan, dievaluasi sudah dan merupakan ikan yang bersifat "invasif dan sangat kompetitif". Kondisi ini menyebabkan ikan-ikan asli/lokal populasi dan kelimpahannya menurun drastis, bahkan disinyalir beberapa jenis ikan sudah hilang dari Danau Beratan. Kondisi ini terjadi karena populasi ikan zebra yang mendominasi perairan, selain itu kemampuan berkembang biaknya sangat cepat, relatif ganas terhadap ikan lain, dan memakan telur-telur ikan lainnya, terutama ikan-ikan ekonomis penting seperti ikan mas, mujair, nila, nilem, dan nyalian.

2. Ikan zebra sangat "Mengganggu Perikanan Budidaya". Kegiatan budidaya ikan mas dan nila dengan sistem jaring kantong apung (Karamba Jakapung) di Danau Beratan tidak bisa berkembang karena ikan zebra masuk ke dalam keramba dan memakan makanan bagi ikanikan target, karena jumlahnya yang sangat berlimpah, petani merasa sangat dirugikan dan ikan target (mas dan nila) kalah kompetisi dengan ikan zebra dalam menangkap makanan.

3. Keberadaan ikan zebra, dikhawatirkan menyebabkan ikan-ikan asli atau lokal mengalami kepunahan karena habitat utama, sarang bertelur dirusak, telurnya dimakan dan bahkan secara bergerombol menyerang. Kondisi ini secara masif akan menyebabkan ikan asli mengalami kepunahan.

4. Karena intensifnya perubahan tata guna lahan di kawasan danau, baik di perairan danau maupun di daerah sekitarnya (khususnya kegiatan pertanian), dikhawatirkan akan terjadi 
pencemaran dan kerusakan habitat pada ekosistem danau. Untuk mencegah kondisi tersebut pada nelayan (kelompok nelayan) mengusukan dilakukan kegiatan pendampingan untuk mengembangkan "Zona Sabuk Hijau (Greenbelt)" dengan menanam tumbuhan air yang tumbuh lokal yaitu bambu air.
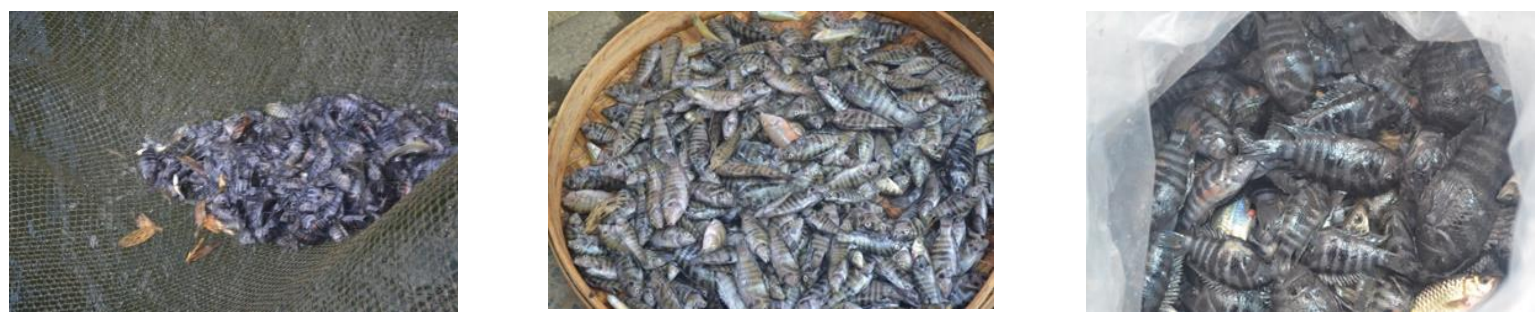

Gambar 3.2 Hasil tangkapan ikan zebra
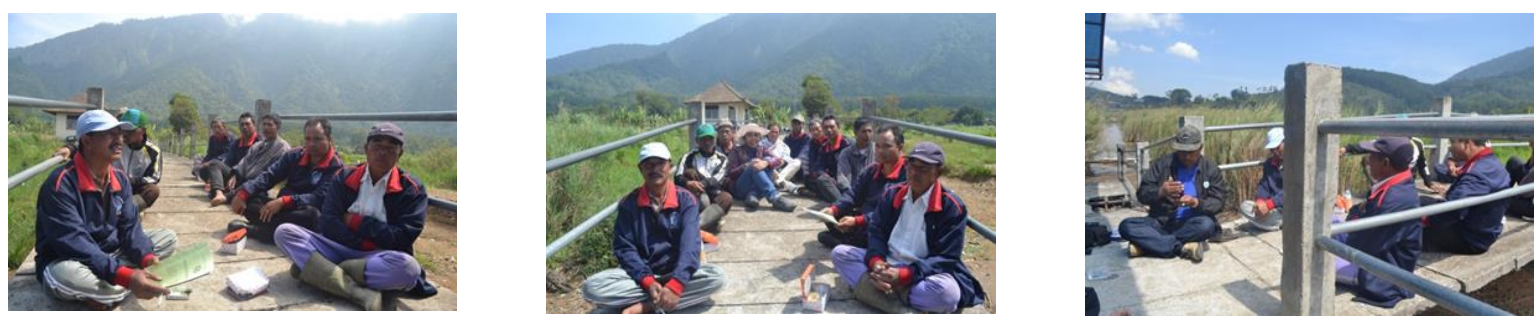

Gambar 3.3 Suasana kegiatan FGD dengan Kelompok Nelayan Mina Puspa Mertha

\section{KESIMPULAN DAN SARAN}

\subsection{Kesimpulan}

1. Lokasi kegiatan pengabdian penangkapan untuk mengurangi populasi ikan zebra dilaksanakan di Danau Beratan pada Kelompok Nelayan Mina Puspa Merta, Desa Kembang Merta, Kabupaten Tabanan, Provinsi Bali.

2. Kegiatan pengabdian mendapat sambutan dan apresiasi yang sangat baik mulai dari Bendesa Adat Kembang Merta, Kelompok Nelayan Mina Puspa Merta, dan juga masyarakat lain yang secara tidak langsung ikut terlibat dalam kegiatan ini. Hal ini terlihat dari antusiasme yang tinggi ketika melalukan penangkapan langsung di beberapa titik di Danau Beratan dan juga pada saat kegiatan diskusi berlangsung.

3. Populasi ikan zebra yang terus meningkat harus segera ditindaklanjuti dengan cara menangkapnya secara berkala, agar ikan-ikan asli atau ikan lokal yang bernilai ekonomis tinggi tidak hilang dari ekosistemnya

\subsection{Saran}

Saran yang dapat diberikan untuk tahapan selanjutnya yaitu terus diadakannya monitoring yang melibatkan Bendesa Adat dan Kelompok Nelayan yang ada di Danau Beratan khususnya Kelompok Nelayan Mina Puspa Merta agar populasi ikan zebra bisa terus stabil dan tidak terjadi peledakan populasi sehingga tidak merugikan para nelayan di sekitar. 


\section{UCAPAN TERIMAKASIH}

Ucapan terimakasih penulis sampaikan kepada Universitas Udayana yang telah mendanai sepenuhnya kegiatan pengabdian ini hingga akhir kegiatan. Penulis juga mengucapkan terimakasih atas kerjasama dari Kelompok Nelayan Mina Puspa Merta dan Bendesa Adat Desa Kembang Merta di Desa Candikuning, Kabupaten Tabanan yang sangat membantu dalam penyelesaian kegiatan pengabdian, serta pihak-pihak terkait lainnya yang telah membantu sehingga kegiatan ini bisa terlaksana dengan baik.

\section{DAFTAR PUSTAKA}

Arthana, I.W., I.W. Suarna, dan I.W.S. Adnyana. 2009. Kondisi Ekosistem Danau-Danau di Provinsi Bali. Prosiding Konferensi Nasional Danau Indonesia I Jilid 2, Bali 13-15 Agustus 2009. Kementerian Negara Lingkungan Hidup. 268-283.

Badan Pusat Statistik Provinsi Bali. 2010. Bali Dalam Angka. Katalog BPS No. 1102001.51: 465p.

Conkel, D. 1993. Cichlids of Nirth and Central America. TFH Publications, Inc., Neptune City, 191 p.

Froese, R. and D. Pauly (eds). 2011. Fish Base. World Wide Web electronic publication. www.fishbase.org, version $(12 / 2011)$.

Hehanussa, P.E. and G.S. Haryani. 2009. Klasifikasi Morfogenesis Danau di Indonesia untuk Mitigasi Dampak Perubahan Iklim. In Konferensi Nasional Danau Indonesia I, Bali.13-15 Agustus 2009. (eds). Kementerian Lingkungan Hidup. Prosiding Konferensi Nasional Danau Indonesia I Jilid 2: Pengelolaan Danau dan Antisipasi Perubahan Iklim. Kementerian Negara Lingkungan Hidup. Jakarta. 298-310.

Lee, G., Grant J.W.A., and Comolli P. 2011. Dominant convict cichlids (Amatitlania nigrofasciata) grow faster than subordinates when fed an equal ration. Behaviour, 148(8):877-887.

Loiselle, P.V. 1995. The cichlid aquarium. Voyageur Press, Germany, 440 p.

Schmitter-Soto, J.J. 2007. A systematic revision of the genus archocentrus (Perciformes: Cichlidae), with the description of two new genera and six new genera and six new species. Zootaxa, 1603: 1-78.

Yamamoto, M.N. and Tagawa A.W. 2000. Hawai'I's native and exotic freshwater animals. Mutual Publishing, Honolulu, Hawaii. 200 p. 